\title{
IMPLEMENTASI TOPSIS UNTUK MENENTUKAN REKOMENDASI MAKANAN ANAK USIA 1-3 TAHUN PADA SISTEM MONITORING TUMBUH KEMBANG ANAK
}

\author{
Fajar Pradana*1, Fitra A. Bachtiar ${ }^{2}$, Rona Salsabila ${ }^{3}$ \\ ${ }^{1,2,3}$ Universitas Brawijaya \\ ${ }^{1}$ fajar.p@ub.ac.id, ${ }^{2}$ fitra.bachtiar@ub.ac.id, ${ }^{3}$ ronasalsabila1391@gmail.com \\ *Penulis Korespondensi
}

(Naskah masuk: 17 November 2021, diterima untuk diterbitkan: 21 Juli 2021)

\begin{abstract}
Abstrak
Penting bagi orang tua untuk memperhatikan pertumbuhan anak secara teratur terutama pada saat periode emasnya. Usia emas pada anak berada pada saat 1000 hari pertama sejak kelahiran atau hingga anak berusia 2 tahun, tumbuh kembang anak dapat meningkat sangat signifikan pada usia ini. Pertumbuhan anak dapat maksimal apabila nutrisi yang diberikan juga tepat sejak usia lahir sampai 3 tahun. Stunting (kerdil) merupakan salahsatu penyakit yang disebabkan karena kurangnya nutrisi pada anak. Stunting adalah sebuah kondisi dimana bayi memiliki panjang dan tinggi badan yang lebih rendah daripada bayi pada umumnya. Pola asuh orang tua terhadap bayi secara mandiri menjadi sangat diperlukan. Untuk membantu orang tua dalam memantau tumbuh kembang anak serta mengurangi peningkatan jumlah bayi stunting maka dibangun sistem monitoring tumbuh kembang anak berbasis web. Pada sistem ini terdapat fitur untuk memberikan rekomendasi makanan berdasarkan kebutuhan kalori setiap anak. Dalam menentukan rekomendasi makanan diperlukan metode Sistem Pendukung Keputusan (SPK) sesuai dengan kebutuhan kalori anak. Dalam penerapan SPK, terdapat metode yang dapat digunakan untuk melakukan analisis data antara lain adalah metode Technique for Order of Preference by Similarity to Ideal Solution (TOPSIS). Alternatif yang digunakan meliputi nama makanan yang dapat dikonsumsi oleh anak usia 1 sampai dengan 3 tahun. Sedangkan kriteria yang digunakan adalah kalori yang didalamnya terdapat karbohidrat, lemak, protein, dan kalsium. 3. Hasil perankingan yang diberikan oleh TOPSIS pada telah berhasil memberikan perankingan dengan nilai yang berbeda-beda, kecuali pada beberapa alternatif. Hal itu dikarenakan kesamaan nilai dari kedua alternatif pada setiap kriteria.
\end{abstract}

Kata kunci: kerdil, tumbuh kembang anak, topsis, sistem pendukung keputusan, rekomendasi makanan

\section{IMPLEMENTATION OF TOPSIS FOR DETERMINING FOOD RECOMMENDATIONS FOR AGES 1st-3 ${ }^{\text {rd }}$ YEARS CHILDREN ON GROWING CHILDREN DEVELOPMENT MONITORING SYSTEM}

\begin{abstract}
It is important for parents to pay attention to the growth of the child in the golden period. The golden age in children remains in the first 1000 days from birth or until the child is born 2 years, child growth and development can increase very significantly at this age. The number of children who can reach a maximum age of 3 years. Stunting is a disease that causes nutritional deficiencies in children. Stunting is a place where babies have a lower length and height than a baby's place in general. Parenting for independent babies is needed. To help parents in developing child growth and development also increase the number of stunting babies a webbased growth and development monitoring system was built. This system provides features to provide food recommendations based on the calorie needs of each child. In determining food recommendations, a Decision Support System (SPK) method is needed in accordance with the calorie needs of children. In the application of SPK, methods that can be used to analyze data include the Technical Method for Preference Order with Similarity to Ideal Solution (TOPSIS). The alternatives used are the names of foods that can be consumed by children aged 1 to 3 years. While the criteria used are calories in fat, fat, protein, and calcium. 3. The ranking results given by TOPSIS have succeeded in ranking them with different values, except for a number of alternatives. That's because it considers the value of the two alternatives on each criterion.
\end{abstract}

Keywords: stunting, food recommendation, topsis, decision support system, kids 


\section{PENDAHUluaN}

Proses tumbuh kembang pada anak idealnya sesuai dengan pertambahan usia anak tersebut. Pertumbuhan anak yang optimal meliputi fisik, kognitif maupun sosial. Penting bagi orang tua untuk memperhatikan pertumbuhan anak secara teratur terutama pada saat periode emasnya. Usia emas pada anak berada pada saat 1000 hari pertama sejak kelahiran atau hingga anak berusia 2 tahun, tumbuh kembang anak dapat meningkat sangat signifikan pada usia ini (Bellieni, 2016). Pertumbuhan anak dapat maksimal apabila nutrisi yang diberikan juga tepat sejak usia lahir sampai 3 tahun. Sedangkan sebaliknya kekurangan nutrisi pada usia emas dapat mengakibatkan kerusakan struktur otak secara permanen, mudah terkena infeksi, serta penyakit kronis lain dikemudian hari (Bellieni, 2016).

Stunting (kerdil) merupakan salahsatu penyakit yang disebabkan karena kurangnya nutrisi pada anak. Stunting adalah sebuah kondisi dimana bayi memiliki panjang dan tinggi badan yang lebih rendah daripada bayi pada umumnya. Berdasarkan data dari World Health Organization (WHO), pada tahun 2005 hingga 2017, bayi stunting di Indonesia menginjak angka $36,4 \%$ atau tertinggi ketiga setelah India di regional Asia Tenggara (Kemenkes RI, 2018). Kondisi ini disebabkan kurangnya pengetahun orangtua terhadap tumbuh kembang anak sehingga asupan nutrisi yang diberikan berada dibawah standar kebutuhan bayi. Pemberian Makanan Pendamping Air Susu Ibu (MPASI) yang sesuai kebutuhan kalori anak dapat mengurangi resiko anak terkena stunting (Kemenkes RI, 2018). Jika stunting tidak dicegah sedini mungkin maka akan berakibat fatal hingga anak beranjak dewasa seperti bentuk tubuh tidak optimal, meningkatnya resiko diabetes serta produktivitas yang kurang optimal (Kalla, 2017).

Untuk mengatasi masalah stunting yang terjadi di Indonesia, pemerintah telah memiliki layanan kesehatan melalui Pos Layanan Terpadu (Posyandu). Posyandu diharapkan dapat membantu orangtua dalam memantau tumbuh kembang anak. Selain itu Posyandu juga dapat mempercepat terwujudnya masyarakat yang sehat. Para orangtua dapat berkonsultasi setiap bulannya terkait perkembangan anak dan nutrisi yang tepat terkait tumbuh kembang anak. Namun berdasarkan data statistik, Posyandu hanya berkontribusi $30 \%$ sedangkan $70 \%$ sisanya tergantung kepada pola asuh dan kemampuan orangtua dirumah dalam memantau tumbuh kembang anak (infodatin,2016). Jumlah anak stunting memiliki porsi yang lebih besar di daerah pedesaan, karena kurangnya pengetahuan orang tua terhadap gizi anak (Lusita, Suyatno dan Rahfiludin, 2017). Sehingga pola asuh orang tua terhadap bayi secara mandiri menjadi sangat diperlukan. Kekurangan dari Posyandu adalah tidak memberikan informasi terkait MPASI yang sebaiknya dikonsumsi anak yang sesuai dengan kebutuhan kalorinya serta minimnya jumlah intensitas pemeriksaan (1 bulan sekali). Sehingga hal ini dapat menyebabkan komposisi makanan anak tidak seimbang sehingga terjadi kekurangan nutrisi pada anak. Komposisi dapat dikatakan seimbang jika memenuhi jumlah karborhidrat, protein, lemak dan kalsium.

Untuk membantu orang tua dalam memantau tumbuh kembang anak serta mengurangi peningkatan jumlah bayi stunting maka dibangun sistem monitoring tumbuh kembang anak berbasis web. Pada sistem ini terdapat fitur untuk memberikan rekomendasi makanan berdasarkan kebutuhan kalori setiap anak. Dalam menentukan rekomendasi makanan diperlukan metode Sistem Pendukung Keputusan (SPK) sesuai dengan kebutuhan kalori anak. Dalam penerapan SPK, terdapat metode yang dapat digunakan untuk melakukan analisis data antara lain adalah metode Technique for Order of Preference by Similarity to Ideal Solution (TOPSIS). Metode ini pertama kali disampaikan oleh Hwang dan Yoon yang menyatakan metode ini yang mampu menganalisa kriteria secara efisien untuk mencari solusi dari alternatif yang ada (Li et al., 2018). Metode TOPSIS digunakan untuk perankingan data, yang memberikan alternatif jarak terdekat dari solusi ideal positif. Solusi ideal positif adalah total semua nilai yang terbaik untuk setiap atributnya. Sebaliknya solusi ideal negatif menampilkan total dari nilai terburuk untuk setiap atributnya (Krohling dan Pacheco, 2015). Parameter yang digunakan untuk menjalankan metode TOPSIS adalah kriteria dan alternatif. Alternatif yang digunakan meliputi nama makanan yang dapat dikonsumsi oleh anak usia 1 sampai dengan 3 tahun. Sedangkan kriteria yang digunakan adalah kalori yang didalamnya terdapat karbohidrat, lemak, protein, dan kalsium.

\section{METODE PENELITIAN}

Penelitian ini dilakukan dalam beberapa tahap. Gambar 1 menunjukan tahap-tahapan yang harus dilakukan mulai dari penentuan kriteria, penentuan alternatif, penentuan bobot untuk setiap kriteria, perhitungan matriks ternormalisasi, pembobotan pada matriks ternormalisasi, penetapan solusi ideal positif dan negatif, perhitungan separation measure, dan penetapan rangking berdasarkan preferensi.

Penelitian ini mengambil objek mengenai rekomendasi makanan untuk anak usia 1-3 tahun. Kriteria perhitungan makanan berdasarkan kebutuhan karbohidrat, lemak, protein dan kalsium. Penentuan bobot masing-masing kriteria tersebut ditentukan berdasarkan nilai rata-rata dari angka kecukupan gizi peraturan Menteri Kesehatan Republik Indonesia No. 8 tahun 2019. Sedangkan alternatif makanan pendamping ASI diperoleh dari 
DKBM (Data Komposisi Bahan Makanan) yang diterbitkan oleh Kementerian Kesehatan Republik Indonesia.

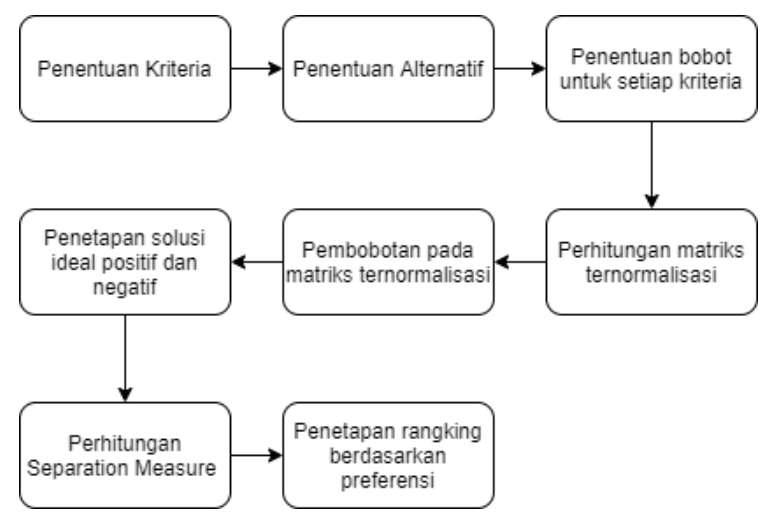

Gambar 1. Metode Penelitian

\section{SISTEM PENDUKUNG KEPUTUSAN}

Sistem pendukung keputusan (SPK) adalah sistem yang digunakan untuk mendukung pengambilan keputusan dalam pada sebuah organisasi atau perusahaan. SPK bukanlah suatu alat bantu dalam pengambilan keputusan, melainkan sebagai alat bantu pendukung (Amaral et al., 2013). SPK dapat juga dikatakan sebagai sebuah sistem komputer yang mengolah data menjadi informasi untuk mengambil sebuah keputusan dari masalahmasalah semi tersetruktur yang spesifik. SPK dapat membantu dalam memberikan alternatif-alternatif keputusan terbaik untuk meningkatkan kemampuan pengambil keputusan dalam menghadapi suatu permasalahan dengan baik. SPK bertujuan untuk meningkatkan efektivitas dan efisiensi dalam pengambilan keputusan.

\subsection{Metode TOPSIS}

Technique for Order of Preference by Similarity to Ideal Solution (TOPSIS) merupakan metode pengambilan keputusan multikriteria yang diperkenalkan oleh Yoon dan Hwang pada tahun 1981. TOPSIS merupakan metode yang didasarkan pada sebuah konsep dimana alternatif terpilih yang terbaik tidak hanya merupakan jarak terpendek dari solusi ideal positif tapi juga memiliki jarak terpanjang dari solusi ideal negatif. Adapun langkahlangkah perhitungan TOPSIS adalah sebagai berikut:

1. Menghitung normalisasi matriks keputusan. Pada TOPSIS, kinerja pada setiap alternatif dapat dilakukan dengan menghitung dengan menggunakan Persamaan 1. Pada Persamaan 1, $x$ adalah nilai alternatif.

$r_{i j}=\frac{x_{i j}}{\sqrt{\sum_{i=1}^{m} x_{i j}^{2}}}$
2. Melakukan pembobotan pada matriks ternormalisasi dengan memberikan bobot seperti Persamaan 2

$$
y_{i j}=w_{i} r_{i j}
$$

Dimana $i=1,2 . ., m ;$ dan $j=1,2, \ldots, n$

3. Menetapkan solusi ideal positif serta negatif. Solusi ideal positif dapat menggunakan persamaan 3 sedangkan solusi ideal postif menggunakan persamaan 4. A+ merupakan notasi Solusi ideal positif sedangkan Amerupakan solusi ideal negatif.

$$
\begin{aligned}
& A^{+}=\left(y_{1}^{+}, y_{2}^{+}, \ldots, y_{n}^{+}\right) \\
& A^{-}=\left(y_{1}^{-}, y_{2}^{-}, \ldots, y_{n}^{-}\right)
\end{aligned}
$$

4. Menghitung Separation Measure untuk setiap solusi alternatif terhadap solusi ideal positif maupun solusi ideal negatif.

Separation measure antara alternatif $A i$ terhadap solusi ideal positif dihitung dengan menggunakan Persamaan 5.

$$
D_{i}^{+}=\sqrt{\sum_{j=1}^{n}\left(y_{i}^{+}-y_{i j}\right)^{2}} ; i=1,2, \ldots m
$$

Separation measure antara alternatif $A_{i}$ terhadapa solusi ideal negatif dihitung dengan menggunakan Persamaan 6.

$$
D_{i}^{-}=\sqrt{\sum_{j=1}^{n}\left(y_{i j}-y_{i}^{-}\right)^{2}} ; i=1,2, \ldots m
$$

5. Menentukan nilai preferensi untuk setiap alternatif dengan menggunakan persamaan 7 .

$$
V_{i}=\frac{D_{i}^{-}}{D_{i}^{-}+D_{i}^{+}} ; i=1,2, \ldots m
$$

\section{SISTEM MONITORING TUMBUH KEMBANG ANAK}

Sistem monitoring tumbuh kembang anak merupakan aplikasi berbasis web yang yang ditujukan kepada orang tua yang memiliki anak berusia 1-3 tahun. Informasi-informasi yang terdapat pada aplikasi ini merupakan informasi yang sudah divalidasi oleh dokter spesialis anak, sehingga informasi yang diberikan dapat dipercaya oleh orang tua. Gambar 2 menunjukan gambaran umum dalam sistem monitoring tersebut.

Salah satu fitur dalam aplikasi ini adalah rekomendasi makanan anak. Sistem akan memberikan ranking berupa rekomendasi alternatif makanan sesuai kebutuhan gizi anak sesuai dengan kebutuhan kalorinya. 


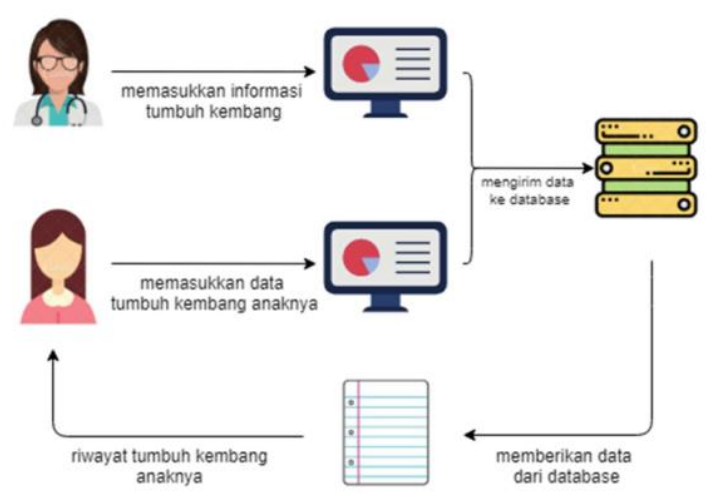

Gambar 2. Gambaran Umum Aplikasi

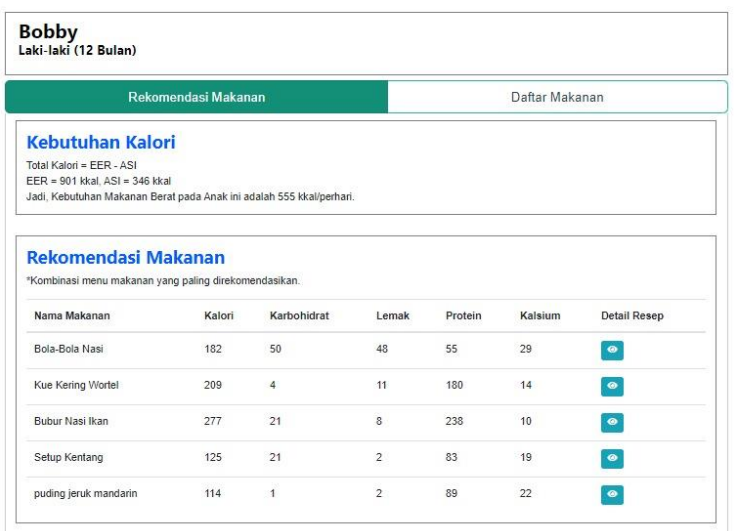

Gambar 3. Tampilan UI rekomendasi

Sebelum menentukan rekomendasi makanan, terlebih dahulu sistem harus menentukan kebutuhan kalori anak. Kebutuhan kalori anak diperoleh dari pengurangan antara nilai Estimated Energy Requirement (EER) dengan energi kebutuhan ASI anak (Sihwi et al., 2016). Untuk mengetahui nilai EER, maka diperlukan berat badan dan usia anak. Gambar 3 menunjukan tampilan UI pada fitur rekomendasi tersebut.

\section{HASIL DAN PEMBAHASAN}

\subsection{Penentuan Kriteria}

Tahapan pertama yang dilakukan dalam penelitian ini adalah menentukan kriteria yang akan dipertimbangkan untuk membuat keputusan. Metode TOPSIS memiliki 2 macam atribut, yaitu cost dan benefit. Atribut cost menunjukkan apabila semakin kecil nilai maka lebih baik, sebaliknya dengan atribut benefit yang menunjukkan apabila nilai semakin besar maka semakin baik. Sedangkan bobot merupakan urutan prioritas, semakin besar bobot maka kriteria tersebut lebih di prioritaskan. Tabel 1 menunjukan kriteria yang digunakan dalam penelitian ini. Bobot dari setiap kriteria ditentukan berdasarkan nilai rata-rata 30 sampel MPASI yang didapatkan dari angka kecukupan gizi yang tertulis pada peraturan Menteri Kesehatan Republik Indonesia No. 8 tahun 2019.

\begin{tabular}{cccc}
\multicolumn{4}{c}{ Tabel 1. Bobot Kriteria Makanan } \\
\hline \multirow{2}{*}{ Kode } & Nama & Bobot & Atribut \\
& Kriteria & Bobot & \\
\hline K1 & karbohidrat & 1.37 & Benefit \\
K2 & lemak & 0.38 & Benefit \\
K3 & protein & 0.145 & Benefit \\
K4 & kalsium & 0.004 & Benefit \\
\hline
\end{tabular}

penentuan alternatif, penentuan bobot untuk setiap kriteria, perhitungan matriks ternormalisasi, pembobotan pada matriks ternormalisasi, penetapan solusi ideal positif dan negatif, perhitungan separation measure, dan penetapan rangking berdasarkan preferensi.

\subsection{Penentuan Alternatif}

Langkah berikutnya adalah menentukan menentukan alternatif yang akan digunakan sebagai objek yang akan dihitung. Pada penelitian ini, alternatif yang digunakan ialah sampel 10 daftar MPASI. Informasi terkait jumlah kalori pada setiap alternatif diperoleh dari DKBM (Daftar Komposisi Bahan Makanan) Indonesia.

\begin{tabular}{cc}
\multicolumn{2}{c}{ Tabel 2. Alternatif sampel MPASI } \\
\hline Kode & Nama Alternatif MPASI \\
\hline A1 & Jus Alpukat \\
A2 & Sari Jeruk Anggur \\
A3 & Pure Pepaya \\
A4 & Pure Pisang \\
A5 & Pure Pisang dan Mangga Harum Manis \\
A6 & Pure melon stroberi \\
A7 & Pure mangga \\
A8 & Pure pir \\
A9 & Pure buah campur \\
A10 & Bubur susu sari wortel \\
\hline
\end{tabular}

\subsection{Penentuan Bobot untuk Setiap Kriteria}

Setelah menentukan alternatif makanan, langkat selanjutnya adalah menentukan bobot dari setiap nilai rentang untuk setiap kriteria. Nilai bobot ditentukan dengan cara membagi rata nilai kalori menjadi 4 bagian dari seluruh 30 data alternatif yang ada. Tabel 3 menunjukan nilai rentang dari setiap kriteria.

Tabel 3. Bobot Kriteria Makanan

\begin{tabular}{ccc}
\hline Kriteria & Nilai rentang & Nilai \\
\hline Karbohidrat (K1) & $0-20$ & 1 \\
& $21-40$ & 2 \\
& $41-60$ & 3 \\
& $61++$ & 4 \\
\hline Lemak (K2) & $0-10$ & 1 \\
& $10-20$ & 2 \\
& $20-30$ & 3 \\
Protein (K3) & $30++$ & 4 \\
\hline Kalsium (K4) & $0-50$ & 1 \\
& $50-100$ & 2 \\
& $100-150$ & 3 \\
& $150++$ & 4 \\
\hline & $0-25$ & 1 \\
& $25-50$ & 2 \\
& $50-100$ & 3 \\
& $100++$ & 4 \\
\hline
\end{tabular}


Setelah menentukan bobot dari setiap nilai rentang, maka langkah selanjutnya membuat matriks alternatif dan kriteria, serta memberikan nilai bobotnya sesuai dengan Tabel 3 .

\subsection{Perhitungan Matriks Ternormalisasi}

Matriks ternormalisasi adalah proses membuat matriks yang ternormalisasi (rij) pada setiap kriteria dan alternatif. Tabel 4 menunjukan hasil perhitungan matriks ternormalisasi.

\begin{tabular}{ccccc}
\multicolumn{5}{c}{ Tabel 4. Matriks Ternormalisasi } \\
\hline Kode & K1 & K2 & K3 & K4 \\
\hline A1 & 1.1094 & 2.1213 & 1.1717 & 0.8528 \\
A2 & 0.2774 & 0.2357 & 0.5208 & 0.2132 \\
A3 & 0.2774 & 0.2357 & 1.1717 & 0.2132 \\
A4 & 0.2774 & 0.2357 & 0.5208 & 0.8528 \\
A5 & 0.2774 & 0.2357 & 1.1717 & 0.8528 \\
A6 & 0.2774 & 0.2357 & 0.5208 & 0.2132 \\
A7 & 0.2774 & 0.2357 & 0.1302 & 0.2132 \\
A8 & 0.2774 & 0.2357 & 0.1302 & 0.2132 \\
A9 & 0.2774 & 0.2357 & 1.1717 & 0.8528 \\
A10 & 0.2774 & 0.2357 & 1.1717 & 0.2132 \\
\hline
\end{tabular}

\subsection{Pembobotan pada matriks ternormaliasi}

Pada langkah ini dilakukan pembobotan pada matriks ternormalisasi dengan memberikan bobot seperti Persamaan 2. Tabel 5 menunjukan hasil pembobotan pada matriks ternormalisasi.

\begin{tabular}{ccccc}
\multicolumn{4}{c}{ Tabel 5. Pembobotan matriks ternormalisasi } \\
\hline Kode & K1 & K2 & K3 & K4 \\
\hline A1 & 1.5199 & 0.8061 & 0.1699 & 0.0034 \\
A2 & 0.3800 & 0.0896 & 0.0755 & 0.0009 \\
A3 & 0.3800 & 0.0896 & 0.1699 & 0.0009 \\
A4 & 0.3800 & 0.0896 & 0.0755 & 0.0034 \\
A5 & 0.3800 & 0.0896 & 0.1699 & 0.0034 \\
A6 & 0.3800 & 0.0896 & 0.0755 & 0.0009 \\
A7 & 0.3800 & 0.0896 & 0.0189 & 0.0009 \\
A8 & 0.3800 & 0.0896 & 0.0189 & 0.0009 \\
A9 & 0.3800 & 0.0896 & 0.1699 & 0.0034 \\
A10 & 0.3800 & 0.0896 & 0.1699 & 0.0009 \\
\hline
\end{tabular}

\subsection{Penetapan Solusi Ideal Positif dan Negatif}

Selanjutnya adalah penetapan matriks solusi ideal positif (A+) dan negatif (A-) yang diperoleh dari hasil normalisasi terbobot dan nilai atribut. Apabila kriteria beratribut benefit, maka ambil nilai tertinggi dari normalisasi terbobot, sebaliknya apabila kriteria beratribut cost, maka diambil nilai terendah. Tabel 6 menunjukan hasil perhitungan solusi ideal positif dan negatif.

\begin{tabular}{|c|c|c|c|c|}
\hline & K1 & K2 & K3 & K4 \\
\hline $\begin{array}{l}\text { Solusi Ideal } \\
\text { Positif }\end{array}$ & 1.5199 & 0.8061 & 0.1699 & 0.0034 \\
\hline $\begin{array}{c}\text { Solusi ideal } \\
\text { negatif }\end{array}$ & 0.3800 & 0.0896 & 0.0189 & 0.0009 \\
\hline
\end{tabular}

\subsection{Perhitungan Separation Measure}

Perhitungan separation measure adalah proses menentukan nilai jarak antara setiap alternatif dengan solusi ideal positif (Di+) dan solusi ideal negatif (Di-). Setelah itu menghitung nilai preferensi untuk setiap alternatif (Vi). Tabel 7 merupakan hasil separation measure dan preferensi.

Tabel 7. Separation Measure dan Preferensi

\begin{tabular}{cccc}
\multicolumn{4}{c}{ Tabel 7. Separation Measure dan Preferensi } \\
\hline Kode & Positif & Negatif & Preferensi \\
\hline Jus Alpukat & 0.0000 & 1.3549 & 1.0000 \\
Sari Jeruk Anggur & 1.3497 & 0.0566 & 0.0403 \\
Pure Pepaya & 1.3464 & 0.1510 & 0.1009 \\
Pure Pisang & 1.3497 & 0.0567 & 0.0403 \\
Pure pisang dan mangga & 1.3464 & 0.1510 & 0.1009 \\
harum manis & 1.3497 & 0.0566 & 0.0403 \\
Pure Melon-Stroberi & 1.3549 & 0.0000 & 0.0000 \\
Pure Mangga & 1.3549 & 0.0000 & 0.0000 \\
Pure Pir & 1.3464 & 0.1510 & 0.1009 \\
Pure Buah Campur & 1.3464 & 0.1510 & 0.1009 \\
Bubur Susu Sari wortel & & &
\end{tabular}

\subsection{Hasil Rangking Preferensi}

Metode TOPSIS yang diimplementasikan dalam sistem ini menggunakan kriteria karbohidrat, lemak, protein dan kalsium. Pengujian data dilakukan dengan menguji 10 sampel MPASI. Dari hasil perhitungan mengunakan TOPSIS, maka diperoleh perankingan terurut seperti tampak pada Tabel 8.

Tabel 8. Hasil Perangkingan

\begin{tabular}{ccccc}
\hline Nama Makanan & Positif & Negatif & Preferensi & Rank \\
\hline Jus Alpukat & 0.00000 & 1.35485 & 1.00000 & 1 \\
Pure pisang dan & 1.34641 & 0.15104 & 0.10087 & \\
mangga harum manis & & & & 2 \\
Pure Buah Campur & 1.34641 & 0.15104 & 0.10087 & 3 \\
Pure Pepaya & 1.34641 & 0.15102 & 0.10085 & 4 \\
Bubur Susu Sari & 1.34641 & 0.15102 & 0.10085 & \\
wortel & & & & 5 \\
Pure Pisang & 1.34971 & 0.05669 & 0.04031 & 6 \\
Sari Jeruk Anggur & 1.34971 & 0.05663 & 0.04027 & 7 \\
Pure Melon-Stroberi & 1.34971 & 0.05663 & 0.04027 & 8 \\
Pure Mangga & 1.35485 & 0.00000 & 0.00000 & 9 \\
Pure Pir & 1.35485 & 0.00000 & 0.00000 & 10 \\
\hline
\end{tabular}

Jika Tabel 8 dikaitkan dengan hasil preferensi, terlihat bahwa Jus Alpokat berada pada posisi pertama. Hal ini karena jus alpokat memiliki kandungan karbohidrat dan protein yang paling tinggi. Metode TOPSIS berhasil memberikan perankingan dengan nilai yang berbeda-beda pada 10

lokasi. Terdapat beberapa makanan yang masih memiliki nilai yang sama. Hal tersebut terjadi karena nilai yang dimiliki kedua alternatif benar-benar sama pada semua kriteria.

\section{KESIMPULAN}

Penelitian dilakukan dengan menggunakan 10 data sampel MPASI. Bobot kriteria didapatkan dengan mengolah data kandungan kalori yang diperoleh dari DKBM (Daftar Komposisi Bahan Makanan) Indonesia.Metode TOPSIS yang diterapakan memberikan perankingan berdasarkan nilai preferensi yang didapatkan dengan menghitung jarak dari solusi ideal positif dan negatif. Hasil perankingan yang diberikan oleh TOPSIS pada telah 
berhasil memberikan perankingan dengan nilai yang berbeda-beda, kecuali pada beberapa alternatif. Hal itu dikarenakan kesamaan nilai dari kedua alternatif pada setiap kriteria.

\section{DAFTAR PUSTAKA}

BELLIENI, C. V, 2016. The Golden 1,000 Days. Journal of General Practice, 04(02), hal.1-4.

KALLA, J., 2017. 100 Kabupaten/Kota Prioritas untuk Intervensi Anak Kerdil (Stunting). 1.

KEMENKES RI, 2018. Buletin Stunting. Kementerian Kesehatan RI, 301(5), hal.1163-1178.

KROHLING, R.A. DAN PACHECO, A.G.C., 2015. A-TOPSIS - An approach based on TOPSIS for ranking evolutionary algorithms. Procedia Computer Science, [daring] 55(Itqm), hal.308-317. Tersedia pada: <http://dx.doi.org/10.1016/j.procs.2015.07.05 4>.

LI, Z., YANG, T., HUANG, C.S., XU, C.Y., SHAO, Q., SHI, P., WANG, X. DAN CUI, T., 2018. An improved approach for water quality evaluation: TOPSIS-based informative weighting and ranking (TIWR) approach. Ecological Indicators, [daring] 89(February), hal.356-364. Tersedia pada: $<$ https://doi.org/10.1016/j.ecolind.2018.02.01 4>.

LUSITA, A., SUYATNO DAN RAHFILUDIN, 2017. Perbedaan Karakteristik Balita Stunting Di Pedesaan Dan Perkotaan Tahun 2017 (Studi Pada Anak Usia 24-59 Bulan Di Wilayah Kerja Puskesmas Gabus Ii Dan Wilayah Kerja Puskesmas Pati Ii Kabupaten Pati). Jurnal Kesehatan Masyarakat (eJournal), 5(4), hal.600-612.

SIHWI, S.W., MULYASARI, H., SAPTONO, R. DAN WIBOWORINI, B., 2016. Sistem Rekomendasi Menu Harian Makanan Pendamping Air Susu Ibu (MPASI) Berdasarkan Kebutuhan Kalori Bayi dengan Metode TOPSIS. Jurnal Ilmu Komputer dan Agri-Informatika, 3(2), hal.122. 